\title{
Short Communication: Dental Trait Variation and Age Determination Based on Dental Wear: A Preliminary Study of Javanese
}

\author{
Myrtati D. Artaria* \\ Department of Anthropology, Universitas Airlangga \\ and \\ Department of Anatomy and Histology, Medical Faculty, Universitas Airlangga, Surabaya, Indonesia
}

\begin{abstract}
This preliminary study describes the dental crown morphology of 14 Javanese of known sex and age. The purpose was to suggest what dental traits to look for when studying a bigger sample from Java. Of 21 traits looked for, traits occurring in the sample were shovel shape, winging, tuberculum dentale, interruption groove, canine distal accessory ridge, premolar accessory
\end{abstract}

Studies in dental anthropology have never been conducted on Indonesians even though the area has a rich variety of peoples and cultures (Muttaqin, 2007). The variety of populations may provide valuable data regarding human evolution (Hillson, 2002), migration patterns (Scott and Turner, 2000), and for solving forensic cases (Brown, 1992), so it is useful to initiate studies in dental anthropology. Before a bigger sample is studied, it is useful to know which dental traits to focus on.

Additionally, the extent of dental wear is useful for estimating an individual's age, especially in skeletal material (Maples and Browning, 1994), so this study also assessed the suitability of a reference base of dental wear rates (Brothwell, 1965, cited in Bass, 1987:287).

\section{MATERIALS AND METHODS}

The sample was 14 individuals (12 females, 2 males) from the island of Java (Indonesia), whose sex and age were known (age range 19 to 26 years). The dental traits examined were shovel shape, incisor winging, tuberculum dentale, interruption groove, canine distal accessory ridge, premolar accessory ridges, premolar odontomes, premolar accessory marginal tubercles, premolar multiple lingual cusps, accessory marginal tubercles, parastyle, cusp 5, cusp 6, Dryopithecus Y5 pattern, cusp 7, protostylid, deflecting wrinkle, anterior fovea, distal trigonid crest, hypocone, and Carabelli's cusp. Dental traits were scored using the descriptions in Scott and Turner (2000). Age estimations from occlusal tooth wear was based on the reference data in Brothwell (1965, cited in Bass, 1987). ridges, premolar accessory marginal tubercles, premolar multiple lingual cusps, cusp 5, cusp 6, Y5 pattern, cusp 7, protostylid, deflecting wrinkle, anterior fovea, hypocone, and Carrabelli's cusp. Dental wear overestimated actual ages because the observed rate of wear was less than in the reference sample. Dental Anthropology 2007;20:42-44.

\section{RESULTS AND DISCUSSION}

Shovel shape was very common. This is expected given the Asian ancestry of the group. Even the canine showed a high incidence of shoveling (Table 1).

Incisor winging occurred in 8 of 14 individuals (57\%). Very high frequencies of winging are usually found in Sinodont dentitions. The people of Java are labeled Sundadont, and these data suggest that Sundadont groups may also have quite high frequencies.

Expression of tuberculum dentale was weak to moderate; only one individual showed a pronounced canine tuberculum dentale. Most individuals lacked a tuberculum dentale on their incisors (Table 2). An interruption groove on the upper second incisors occurred in half the sample ( $7 / 14$ cases).

TABLE 1. The number of teeth with shovel-shape

\begin{tabular}{lrrrrrr}
\hline & \multicolumn{3}{c}{ Maxilla } & \multicolumn{3}{c}{ Mandible } \\
& I1 & I2 & C & I1 & I2 & C \\
\hline No shovel & 1 & 1 & 1 & 12 & 12 & 1 \\
Shovel & 13 & 13 & 13 & 2 & 1 & 13 \\
Total & 14 & 14 & 14 & 14 & 13 & 14 \\
\hline
\end{tabular}

*Correspondence to: Myrtati D. Artaria, Department of Anthropology, Universitas Airlangga, Jl. Airlangga 4-6, Surabaya 60286, Indonesia E-mail: mdartaria_fisip@unair.ac.id, myrtati@yahoo. co.id 
TABLE 2. The occurrence of tuberculum dentale

\begin{tabular}{lrrr}
\hline & I1 & I2 & C \\
\hline No tuberculum dentale & 13 & 12 & 1 \\
Weak & 0 & 1 & 4 \\
Moderate & 1 & 1 & 8 \\
Pronounced & 0 & 0 & 1 \\
Totals & 14 & 14 & 14 \\
\hline
\end{tabular}

Canine distal accessory ridge was uncommon, and when it appeared, the expression was not very strong (score 1 to 3) (Table 3). Premolar accessory ridges appeared mostly in the lower premolars. The occurrence was $1 / 14$ on $P 1$ and $7 / 14$ in the maxilla, while frequncies of $7 / 14$ and $6 / 14$ occurred on the mandibular premolars.

Three-cusped second molars were found $(1 / 26$ M2), but most molars had 3 or 4 main cusps (Table 4). Carabelli's trait complex was expressed in half of the cases. However, the expression was in the form of the most subtle expression (A).

The expression of several dental traits is summarized in Table 5. Anterior fovea was expressed in most cases. A second trait that was expressed quite often (8 instances) was lower premolar multiple lingual cusps. Dental traits not found in the sample were accessory marginal tubercles, parastyle, and odontome.

Occlusal dental wear was less severe than in the reference data (Brothwell, 1965, cited in Bass, 1987). It would be logical to predict that most teeth in modern humans have less dental wear due to the softer, cooked material eaten, compared to their predecessors. However, modern humans may exhibit tooth abrasion if brushing with an abrasive toothpaste (Hillson, 2002).

The finding of little dental wear in these Javanese compared to the reference sample emphasizes variations in rates among populations, based on tooth cleaning practices, nature of the diet, and cultural practices related to utilizing teeth as tools. We used Brothwell's occlusal wear rates that were derived from British archeological material. The present results show that dental wear reference data should be used cautiously, taking into account the origin of the individual being assessed. It seems that the cultural practices and habits of contemporary Javanese do not cause as much dental
TABLE 3. The occurrence of canine distal accessory ridge

\begin{tabular}{lrlllll}
\hline & 0 & 1 & 2 & 3 & 4 & 5 \\
\hline Upper & 9 & 1 & 3 & 1 & 0 & 0 \\
Lower & 11 & 1 & 2 & 0 & 0 & 0 \\
\hline
\end{tabular}

wear as from harder food material eaten by more ancient humans.

\section{CONCLUSIONS}

Based on the dental traits, most ( 6 out of 7 ) of the dental characteristics of Southeast Asian people (Scott and Turner, 2000) have been found in the sample. Besides these seven dental traits, tuberculum dentale, canine distal accessory ridge, premolar accessory ridges, premolar multiple lingual cusps, protostylid, and anterior fovea were also found in the sample. Further research on this area should be done with larger sample sizes, and the traits looked for need not be limited to the dental traits indicated as the characteristic of Southeast Asian people.

Dental wear in this sample indicated older age of individuals compared to the real ages because of slow

TABLE 5. The occurrence of several dental traits

\begin{tabular}{lc}
\hline \multicolumn{1}{c}{ Dental Trait } & $\begin{array}{c}\text { Frequency } \\
\text { (individuals) }\end{array}$ \\
\hline Odontome & 0 \\
Premolar accessory marginal tubercle & 3 \\
Lower premolar multiple lingual cusps & 8 \\
Accessory marginal tubercles & 0 \\
Parastyle & 0 \\
Cusp 5 & 1 \\
Cusp 6 & 3 \\
Y-5 Pattern & 1 \\
Cusp 7 & 1 \\
Protostylid & 2 \\
Deflecting wrinkle & 1 \\
Anterior fovea & 13 \\
Distal trigonid crest & 0 \\
\hline
\end{tabular}

TABLE 4. Size gradations of the hypocone

\begin{tabular}{cccccccccrrrr}
\hline & \multicolumn{1}{c}{ Right Side } & \multicolumn{7}{c}{ Left Side } \\
Molar & 0 & 1 & 2 & 3 & 4 & 5 & 0 & 1 & 2 & 3 & 4 & 5 \\
\hline M1 & 0 & 0 & 0 & 1 & 11 & 1 & 0 & 0 & 0 & 1 & 13 & 0 \\
M2 & 1 & 0 & 2 & 9 & 0 & 0 & 2 & 0 & 0 & 11 & 1 & 0 \\
\hline
\end{tabular}


wear rates, so aging an individual using dental wear reference data should be done cautiously. However, because of the small sample size, more people should be included in the future study.

\section{ACKNOWLEDGEMENTS}

My gratitude to all the students that have been willing to give their dental impressions. My greatest appreciation to Susy Kristiani, drg., MKes who have given her time and suggestions for the techniques in making dental casts.

\section{REFERENCES CITED}

Bass WM. 1987. Human osteology: a laboratory and field manual, 3rd edition. Columbia: Missouri Archaeological Society, Inc.
Brown KA. 1992. Comparative bite marks: differential diagnosis. In: Clark DH. Practical forensic odontology. London: Butterworth-Heinemann Ltd.

Hillson S. 2002. Dental anthropology. Cambridge: Cambridge University Press.

Maples WR, Browning M.1994. Death in 10,000 fragments. In: Maples WR and Browning M, editors. Dead men do tell tales. New York: Doubleday.

Muttaqin T. 2007. Indonesian culture and society. Online at http://www.budpar.go.id/ filedata/915_152Indonesiaculture1.pdf. Accessed 21 August 2007.

Scott GR, Turner CG II. 2000. The anthropology of modern human teeth. Cambridge: Cambridge University Press. 